\title{
木材生産構造の変遷からみた地域における林業・木材業産地の形成
} 和歌山県田辺における山長商店を中心とした事業者間の取引関係の考察を通して

\section{FORMATION OF THE AREA OF FORESTRY AND WOOD INDUSTRY IN THE REGION \\ FROM THE VIEWPOINT OF TRANSITION OF WOOD PRODUCTION STRUCTURE}

Through consideration of business relationships between businesses centered on Yamacho-Shoten in Tanabe, Wakayama Prefecture

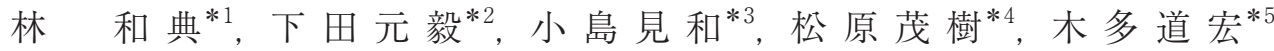 \\ Kazunori HA YASHI, Motoki SHIMODA, Mina KOJIMA, Shigeki MATSUBARA and Michihiro KITA}

\begin{abstract}
The purpose of this study is to clarify the formation of the area of forestry and wood industry in the region from the viewpoint of transition of the wood production structure through consideration of business relationships between businesses centered on Yamacho-Shoten in Tanabe, Wakayama Prefecture. It was found that Yamacho-Shoten has built a mutually complementary relationship with various businesses in the region with the integrated wood production system of foresting, sawing, processing, and selling. The wood production structure of Yamacho-Shoten resists the decline in regional vitality and guarantees the continuation of other forestry and wood production businesses.
\end{abstract}

Keywords : Forestry, Wood Industry, Wood Production, Network, Integrated Production, Regional Formation 林業, 木材業, 木材生産, ネットワーク, 一貫生産, 地域形成

\section{1. 序論}

\section{1-1. 研究の背景}

日本の林業・木材業注 1)には、山林での植林・保育・伐採による素 材生産、都市部近郊での製材・加工、都市部での木造住宅建設への 消費、という木材の循環の中で形成されてきた側面がある。昭和 30 年代まで盛んに行われていた筏流しによる木材流送は、奥地の山林 と河口部の製材産地の間に流通ネットワークを構築し、河川流域を 単位とする林業・木材業産地を形成した。第二次世界大戦後のトラ ックによる木材輸送は、河川流域単位であった素材生産と製材の流 通ネットワークを分離させ、外材素材輸入による港湾製材所の大規 模化は、分離の傾向をより顕著にした。

近年は、林業・木材業や建設業に関わる多様な事業者の連携が求 められ 1)、素材生産から製材、販売までを一貫して行う「林業の 6 次産業化」や、地域内で各事業者がネットワークを形成し「顔の見 える関係」で地域産材を利用した住宅を作る動き等がみられる注 2)。 このような連携を実現するためには、地域の山林資源や事業者の特 質を理解し、各事業者を情報や流通の面で繋げる中心となる事業者
や組合の存在が必要である 2),3)。林業・木材業者やその生産活動にお けるネットワークの形成過程を明らかにすることは、林業・木材業 の持続や地域の発展において重要である。

\section{1-2. 研究の目的}

和歌山県は江戸時代より「木の国」と呼ばれるほど林業・木材業 が盛んであり、各河川流域に林業・木材業産地が形成された 4)。戦 後のトラック輸送により、流域内で完結していた木材生産構造やネ ットワークは広域化し、素材生産と製材の分離により流域ごとのま とまりが弱まった。高度経済成長期に、和歌山市、御坊、田辺、新 宮等では外材製材により製材業が繁栄したが、現在は素材生産量・ 外材輸入量共に減少し、多くの製材所が製品生産から撤退、廃業又 は二次加工や製品販売への転換を行うなど、林業・木材業は衰退し ている。

本研究は、県の林業・木材業の中心を担う田辺市の山長商店を対 象とする。山長商店は、江戸時代に木炭商として創業した、約 6,000ha の山林を所有する林業経営体である。「林業の 6 次産業化」 を推進しており、植林から保育、素材生産、製材、プレカット加工、
*1 大阪大学大学院工学研究科地球総合工学専攻 博士後期 課程・日本学術振興会特別研究員 (DC) ・ 修士 (工学)

*2 大手前大学建築 ·芸術学部 専任講師 ·博士（芸術）

*3 大阪大学大学院工学研究科地球総合工学専攻 助教・博士 (工学)

*4 大阪大学大学院工学研究科地球総合工学専攻 准教授・博士 (工学)

* 5 大阪大学大学院工学研究科地球総合工学専攻 教授・博士 (工学)
Grad. Student, Division of Global Architecture, Graduate School of Engineering, Osaka University, JSPS Research Fellow (DC), M.Eng.

Junior Assoc. Prof., Faculty of Architecture and Arts, Otemae University, Dr.Arts Creative.

Assist. Prof., Division of Global Architecture, Graduate School of Engineering, Osaka University, Dr.Eng.

Assoc. Prof., Division of Global Architecture, Graduate School of Engineering, Osaka University, Dr.Eng.

Prof., Division of Global Architecture, Graduate School of Engineering, Osaka University, Dr.Eng. 
販売に至るまで、グループ会社で一貫して行っている。山長商店が 地元山林資源と都市部の木造住宅需要を、「顔の見える関係」で埼玉 県の販売部門を介して架橋する木材生産・供給の仕組みは、平成 25 年にグッドデザイン賞に選ばれた ${ }^{3}$ 3)。また、山長商店の前会長と現 会長は和歌山県木材協同組合連合会会長や田辺木材協同組合理事長 等の複数の公職を務め、地域のまとめ役を担ってきた。

以上のことから山長商店は、地域内外に広く生産・販売のネット ワークを構築し、田辺の林業・木材業産地を形成してきた主体の一 つであり、地域の核であると捉えることができる。本研究では、歴 史的に林業・木材業が栄えた田辺港の文里湾沿岸に位置する新庄地 域と周辺の田辺市街地を一体と捉え、平成の大合併以前の田辺市域 を「田辺」と定義する。本研究は、山長商店とそれに関わる田辺の 事業者との関係を詳細に把握することで、山長商店を中心とした田 辺全体の木材生産構造の変化を明らかにすること、さらに、林業・ 木材業産地形成の観点から木材生産構造の変化の意味を捉え直し、 山長商店と小規模な事業者が地域で共存し、林業・木材業産地を形 成してきた原理を解明することを目的とする。

\section{1-3. 研究の位置付け}

本研究に関寸る先行研究は、(1)地域産業空間の形成、(2)和歌山県 の林業・木材業、(3)木材生産構造の 3 テーマに分けられる。地域産 業空間の形成のテーマは建築・都市計画の分野に、和歌山県の林業・ 木材業のテーマは林業経済の分野に、木材生産構造のテーマは双方 の分野に研究の蓄積が多い。

\section{(1)地域産業空間の形成}

堀尾ら 5)は、群馬県桐生において、豊富な水資源を利用した織物 産業の地理的展開を明らかにすることで、地域の社会的資産の再評 価を行い、地域特性を活か寸まちづくりの重要性を訴えた。大熊ら 6)は、住工共存地区における近接性を活かした産業ネットワークの 形成、個人的繋がりの業務上の繋がりへの発展可能性、居住と産業 の隣接によるネットワークの構築・重層の重要性を明らかにした。

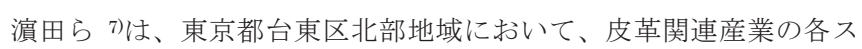
テークホルダーの立地傾向とそれに対応した居住空間・都市空間の 実態と変遷を明らかにし、地域内外の産業構造と居住構造の相補的 更新が持続的な産業都市空間に必要である知見を得た。

以上のように、地域づくりにおける地域固有の産業の重要性や、 地域産業の継続・発展における産業と住民の関わり方や事業者間の ネットワークの重要性が指摘されている。

\section{(2)和歌山県の林業・木材業}

萩野ら ${ }^{8)}$ は、河川を利用した木材流送によって古くから林業・木 材業の栄えた新宮と、インフラ整備と戦後木材需要が結び付き発展 した新興地である田辺の木材市場の比較を行い、田辺木材市場が素 材や販売先の確保において優位性を発揮し、既存市場の新宮を脅か 寸存在であったことを明らかにした。有水 ${ }^{9}$ は、紀南の河川流域に 発達した他林業・木材業産地と田辺を比較し、土地や港湾及び既存 システムに囚われなかった田辺の林業・木材業の発展を指摘した。 野村 ${ }^{10}$ は、和歌山市・田辺・新宮の 3 市場の素材入荷や製品販売の 地域別や量を比較し、素材を河川流送に依存する新宮木材市場と県 外移入に依存する和歌山木材市場に対し、インフラ整備、大資本力、 銘柄材の販売等から、田辺木材市場が飛躍的に発展したことを明ら かにした。有木 ${ }^{11}$ は、和歌山県の龍神(現田辺市)において、第一次
石油危機後の低成長下に、村内外在住の森林所有者が組織化し、原 木市場設立や施業見直しによる改革を行い、山林所有者や素材生産 者等の山元が主体的に生産や施業の改革を行うことの重要性を明ら かにした。

以上のように、戦後成長下にあった和歌山県田辺の林業・木材業 は、飛躍的発展に着目した多くの報告がなされた。その後、第一次 石油危機後の低成長下における、龍神の山元主導の取り組みが報告 されたが、近年は和歌山県の林業・木材業に関する調查研究は見ら れない。

\section{(3)木材生産構造}

幡 ${ }^{12)}$ は、国の製材所大規模化政策である新生産システムによって 拡大した熊本・大分両圈域モデルにおいて、製材機械や乾燥機等へ の設備投資が行われた一方、素材供給力不足が課題であることを明 らかにした。大地ら ${ }^{13}$ は、大分県日田地域の製材所が素材不足を補 うために、市場での競りを介さず素材生産者等から直接素材を購入 する直送を増加させ対応していることを報告した。

一方、半田 ${ }^{14}$ は、農山村等の地域産業や地域組織の持続・発展の 観点からは顔の見える関係や協業化が重要であり、経済至上主義に よる闇雲な林業・木材業の大規模化傾向は好ましくないことを主張 した。白井 ${ }^{2)}$ は、岐阜県長良川流域において、市町村界を超えた範 囲における木材生産と木材利用について詳細な調查を行い、地域の 木造住宅に地域産材が供給されておらず、地域住宅産業が地域林業 に寄与していない実態を明らかにした。津倉ら 15)は、かつて天竜川 流域において形成されていた社会的ネットワークが、個人的な繋が りの継続によって再構築されていることを明らかにし、流域圈を単 位とした産業地域の再構築のための条件が産業集積地と社会的ネッ トワークの存在であることを明らかにした。足立ら 3は、従来の木 材流通の多段階性によるコスト増等のデメリットの克服に対し、川 下から川上までの主体間の情報流構築の重要性を明らかにした。

以上のように、近年の製材加工の大規模化に如何に対応するかを 検討する報告がまとまった成果をあげる一方、地域産業として事業 者の協力関係やネットワークの構築が重要であるという視点も生ま れている。旧来の河川流域における木材生産構造が変容・解体され る中、その実態と課題を明らかにしつつ、元々の事業者間の連携を 生かしながら新たな木材生産構造のあり方を模索しょうとする取り 組みは、本論文に重要な示唆を与えるものである。

本研究は、林業・木材業を基盤として形成された地域において、 事業者間のネットワークの特徵を明らかにし、新たな木材生産構造 のあり方を追求しようとする点で、前述した既往研究と同じ立場で ある。流域に囚われず発展を遂げてきた田辺において、林業・木材 業の中心を担う存在である地域事業者のネットワークが如何に構築 され、林業・木材業が継続されてきたのかを明らかにすることで、 将来の木材生産構造のあり方を構想寸るための知見を提供し得る点 で意義がある。また、近年研究蓄積の少ない、和歌山県における林 業・木材業の持続に向けた考察を、地域資源や事業者の関わり合い 等の視点から行う点でも意義がある。

\section{2. 研究方法}

\section{2-1. 研究方法と論文の構成}

本研究では、まず、田辺の林業・木材業の素材の利用や入荷の状 
Table1 Interview List ～ヒアリングリスト

\begin{tabular}{|c|c|c|c|}
\hline 分類 Category & 名前 Name & 分類 Category & 名前 Name \\
\hline $\begin{array}{l}\text { 山長グループ } \\
\text { Yamacho Group }\end{array}$ & $\begin{array}{l}\text { 山長商店 } \\
\text { Yamacho-Shoten } \\
\text { 山長林業 } \\
\text { Yamacho Forestry }\end{array}$ & \multirow{2}{*}{$\begin{array}{c}\text { 行政 } \\
\text { Administration }\end{array}$} & \multirow{2}{*}{$\begin{array}{l}\text { 和歌山県庁 農林水産部 } \\
\text { Agriculture, Forestry } \\
\text { and Fisheries Division of } \\
\text { Wakayama Prefectural } \\
\text { Office } \\
\text { 田辺市役所 農林水産部 } \\
\text { Agriculture, Forestry } \\
\text { and Fisheries Division of } \\
\text { Tanabe City Office }\end{array}$} \\
\hline $\begin{array}{c}\text { 素材生産者 } \\
\text { Forestry } \\
\text { Organization }\end{array}$ & $\begin{array}{l}\text { A 林業 A Forestry } \\
\text { B林業 B Forestry } \\
\text { C林業 C Forestry }\end{array}$ & & \\
\hline $\begin{array}{l}\text { 製材所 } \\
\text { Sawmill }\end{array}$ & $\begin{array}{ll}\text { D製材 } & \text { D Sawmill } \\
\text { E 製材 } & \text { E Sawmill } \\
F \text { 製材 } & \text { F Sawmill } \\
\end{array}$ & \multirow[b]{2}{*}{$\begin{array}{c}\text { 組合 } \\
\text { Association }\end{array}$} & \multirow{2}{*}{$\begin{array}{l}\text { 和歌山県木材 } \\
\text { 協同組合連合会 } \\
\text { Federation of Wakayama } \\
\text { Prefectural Lumber } \\
\text { Cooperative Association } \\
\text { 田辺木材協同組合 } \\
\text { Tanabe Lumber } \\
\text { Cooperative Association }\end{array}$} \\
\hline $\begin{array}{l}\text { 原木市場 } \\
\text { Log Market }\end{array}$ & $\begin{array}{l}\text { 田辺木材共販所 } \\
\text { Tanabe Market } \\
\text { 龍神木材共販所 } \\
\text { Ryujin Market } \\
\text { 新宮原木市場 } \\
\text { Shingu Market }\end{array}$ & & \\
\hline
\end{tabular}

況における転換点を基準に時期区分を行い、概要と変遷の特徵を整 理する (3 章)。次に、田辺と山長商店の林業・木材業に関する数量を 把握し比較することによって、田辺の木材生産における山長商店の 占める割合を把握し、山長商店の数量的な位置付けを明らかにする (4 章)。その上で、山長商店の木材生産構造の変遷を取引先やその地 域、量等の変遷から把握し、地域との連関や特徽を明らかにする (5 章)。5 章までで明らかになった内容を基に、山長商店の木材生産構 造が田辺の林業・木材業に与えた影響について考察し(6 章)、結論と 展望についてまとめる(7 章)。

\section{2-2. 木材生産構造の定義}

木材生産構造とは、素材の箋流しからトラック運送へ変化した木 材流通や、現在多くみられる大規模製材所が素材を大量に購入し製 材する生産体制等、地勢や社会的ネットワークの変化と共に構築、 再編成されてきた、地域や事業者固有の木材流通や生産体制のこと である。

\section{2-3. 調査方法}

本研究は、主にヒアリング調査と文献調査を基本として行った。 令和元年 11 月〜令和 2 年 1 月の期間および令和 3 年 2 月にヒアリ ングを行い、文献調査と組み合わせることで田辺や山長商店の林業 や木材生産構造の変遷を明らかにした。ヒアリング内容は対象の業 種別に、(1)全事業者：仕事内容／創業年/従業員数等、(2)素材生産 者: 素材生産を行う地域／素材生産量／素材販売先等、(3)製材所 : 素材購入元 /製品販売先 / 素材消費量 / 取扱素材種類等、(4)行政 · 組合 : 事業者名簿 /事業者の数や特徴/素材生産量 / 外材 / 組合の
基本情報 / 林業・木材業の歴史等である。ヒアリング対象は表 1 の 通りである。行政や組合へのヒアリング調查から、田辺には 5 つの 素材生産者と 8 つの製材所があることが分かり(平成 30 年時点)、そ の内 4 つの素材生産者と 4 つの製材所をヒアリング調查対象とし た。また、県内に 4 つある原木市場の内、競りを行い市場としての 機能を持つ 3 つの市場にヒアリング調查を行った。文献調查は和歌 山県や田辺の林業・木材業の歴史に関する書籍 4),16),17)や、山長商店 の現会長が日刊木材新聞にて執筆した新聞記事. 18, 注4)を参照した。

\section{3. 田辺の林業・木材業と時期区分}

田辺の林業・木材業は、木炭生産から始まった。大河川の存在し ない田辺では、大規模な素材生産や製材の発展は紀伊半島の他地域 に後れを取った。大正 8 年に完成した索道を利用した奥山からの素 材流入と、機帆船を利用した東京への販売により製材業が発展した。 戦後復興や米材輸入を受け規模拡大したが、石油危機やバブル崩壊、 ウッドショック注5)等を受け低迷、多くの製材所が閉鎖した 4),16)。

本研究では、田辺の林業・木材業を概観し変遷の特徵を整理する ために、素材の利用や入荷の状況において大きな転換点となる、昭 和 36 年の「米材輸入開始」、昭和 48 年の「第一次石油危機」、平成 10 年の「米材輸入停止」を画期とし、4つの時期に区分する。米材 輸入以前を田辺の林業・木材業の基盤が確立した「国産材製材発展 期」、第一次石油危機までを米材輸入量増加と米材製材所の大規模化 が起こった「米材製材隆盛期」第一次石油危機以降の米材輸入量が 減少した「米材製材低迷期」、米材輸入終了後に国産材一転換した「国 産材製材転換期」とし(図 1)、概要と変遷の特徵を整理する。

3-1. 国産材製材発展期（昭和 21 年 35 年)

田辺では、戦後復興や朝鮮戦争による木材需要増加を受け、製材 所の新設、規模拡大が行われた。素材不足を補うため、昭和 20 年代 後半に県内各地や四国、中国、九州からも素材が移入されるように なった 4),16)

製品の販売先は、東京市場での木材の需要増加、価格高騰を受け、 大阪中心から昭和 30 年頃には東京中心となった。交通網が未整備 であった当時、高品質な田辺の製品を機帆船により大量かつ安価に 出荷していた ${ }^{4), 16)}$

\section{3-2. 米材製材隆盛期（昭和 36 年 昭和 47 年）}

製材所の増大による素材不足解消を目指し、昭和 36 年に田辺港 への米材輸入が始まった。大規模製材所の多くが、安価かつ大量に 購入可能な米材の利用へ移行し、概して大規模な米材製材所と中小

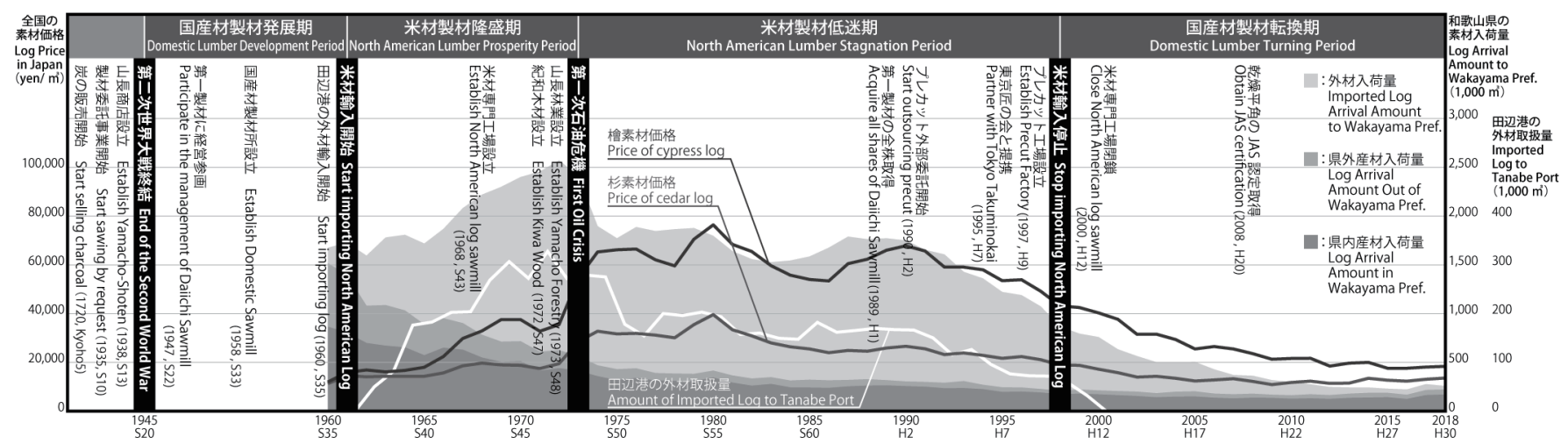

Fig.1 Chronology of Yamacho-Shoten and fluctuation in log price and arrival $/$ 山長商店の年表と素材価格 · 入荷量の変動 
規模な国産材製材所に分化した。米材輸入開始 2 年後の昭和 38 年 には、米材製材量が国産材製材量を超え、昭和 45 年には国産材の 8 倍もの米材が田辺へ入荷した。需要の低下した国産材は、県外から の入荷はほぼなくなり、県内産材の製材が主となった。中小規模製 材所は地元の大工や工務店への販売が多く、大規模製材所は関東の 卸売業者への販売が中心であった ${ }^{4), 16), 17) 。 ~}$

\section{3-3. 米材製材低迷期（昭和 48 年 平成 10 年）}

第一次石油危機以降、田辺港の米材輸入は減少傾向となった。さ らに、平成 3 年のバブル崩壊による景気低迷と、平成 4 年のウッド ショックによる米材価格高騰を受け、米材輸入の減少は加速した。 概して大径・長木の米材から小径の国産材への利用素材の転換は、 大規模米材製材所にとって設備・技術的に困難を伴うものであった。 平成 4 年から平成 8 年の間に 5 工場が閉鎖し、平成 10 年に田辺港 の米材輸入は幕を閉じた。一方、田辺への国産材入荷量は横ばいで あった。昭和 50 年前後の御坊、龍神、田辺、本宮といった県南部で の原木市場開設以降、国産材製材所の素材入荷は、素材生産者から の直接購入や自社生産から、市場での購入に移行した。東京ではド 一ナツ化現象により郊外での建設需要が増加したため、東京郊外の 小売業者や製品市場への販売が増加した。小規模製材所は地域内生 産・販売を継続した $\left.{ }^{4)}, 16\right) 。$

\section{3-4. 国産材製材転換期（平成 11 年 ）}

田辺港の米材輸入終了後、国内の他地域から移入された米材を利 用した製材が一部継続されたが、平成 23 年の米材製材所の倒産に より、田辺の米材製材所はなくなった。国産材製材所は、閉鎖する ものや建材販売に業態を替えるものが多かった。田辺の製材所は、 大規模製材所である山長商店とグループ会社の第一製材と 6 社の小 規模製材所のみとなった。また、和歌山県の原木市場は田辺木材共 販所、龍神木材共販所、御坊木材共販所、新宮原木市場の 4 つとな った。販売先は、昔から関東へ販売していた事業者は関東へ、地元 へ販売していた事業者は地元への販売を継続している 16$) 。$

\section{3-5. 小結 : 田辺の林業 · 木材業の盛衰と米材輸入の功罪}

戦後、田辺の林業・木材業は、都市部の戦後復興や朝鮮戦争等の 木材需要増加を主要因に、港湾や道路等のインフラ整備を基盤とし て、豊富な米材供給を受け発展することができた。一方、米材の隆 盛に反比例するように、国産材の素材生産、製材は縮小した。米材 製材隆盛期において、米材輸入が田辺の製材業の発展を促したが、 多くの製材所はその後の国産材への回帰を成し遂げることはできな かった。一方、山長商店は製材業を継続・発展させてきた。そこで 次章では、田辺の林業・木材業に関寸る数量を把握し、山長商店が 占める割合に関して分析を行う。

\section{4. 田辺の木材生産構造と山長商店の発展}

山長商店は江戸中期に炭の商売を始め、山林業を生業としていた。 昭和 10 年、自社工場を持たなかった山長商店は、後にグループ会 社となる第一製材への加工依頼をすることを契機に製材業に進出し た。戦後、自社林を活用した国産材製材と大規模米材製材を両立し、 木材価格の高騰した昭和 40 年代後半には林業、販売、不動産、砕石 等、山林業に関する様々な会社を立ち上げた。米材輸入減少・素材 価格低迷を受け、製品価値を高めるプレカット事業に進出し現在に 至る注 6)
Table2 Quantitative data on the forestry and wood industries of Tanabe and Yamacho-Shoten 田辺と山長商店の林業・木材業に関する数量データ

\begin{tabular}{|c|c|c|c|c|c|c|c|}
\hline \multirow{2}{*}{$\begin{array}{l}\text { 年 } \\
\text { Year }\end{array}$} & \multirow{2}{*}{$\begin{array}{l}\text { 田辺の } \\
\text { 製材所数 } \\
\text { The number } \\
\text { of sawmills } \\
\text { in Tanabe }\end{array}$} & \multicolumn{3}{|c|}{$\begin{array}{c}\left.\text { 田辺への素材入荷量 ( } \mathrm{m}^{3}\right) \\
\text { Log arrival amount to Tanabe }\end{array}$} & \multicolumn{3}{|c|}{$\begin{array}{c}\text { 山長商店の素材消費量 }\left(\mathrm{m}^{3}\right) \\
\text { Log Consumption in Yamacho }\end{array}$} \\
\hline & & $\begin{array}{l}\text { 国産材 } \\
\text { Domestic }\end{array}$ & $\begin{array}{c}\text { 米材 } \\
\text { North } \\
\text { American }\end{array}$ & $\begin{array}{l}\text { 計 } \\
\text { Total }\end{array}$ & $\begin{array}{l}\text { 国産材 } \\
\text { Domestic }\end{array}$ & $\begin{array}{c}\text { 米材 } \\
\text { North } \\
\text { American }\end{array}$ & $\begin{array}{l}\text { 計 } \\
\text { Total }\end{array}$ \\
\hline S33 (1958) & 42 & 200,000 & 0 & 200,000 & 13,773 & $\overline{0}$ & 13,773 \\
\hline S45 (1970) & 37 & 42,000 & 328,700 & 370,700 & 10,041 & 43,126 & 53,167 \\
\hline H7 (1995) & 24 & 50,000 & 73,000 & 123,000 & 14,754 & 20,177 & 34,931 \\
\hline H30 (2018) & 8 & 35,000 & 0 & 35,000 & 28,213 & 0 & 28,213 \\
\hline
\end{tabular}

本章では、田辺の製材所数の変化や、田辺の素材入荷量と山長商 店の素材消費量の比較(表 2)を分析し、田辺の製材業に占める数量的 割合の変遷を把握することで、山長商店が如何に事業を展開してき たかを明らかにする。米材製材低迷期までのデータは文献調查 4),16),17) とヒアリング調査から、国産材転換期のデータはヒアリング 調査からまとめた。

\section{4-1. 国産材製材発展期（昭和 21 年 35 年）}

田辺の製材所数は、終戦直後の約 15 工場から昭和 33 年の 42 工 場へ増加し、 1 工場当たりの能力は、昭和 28 年の $24.9 \mathrm{~kW}$ から昭和 33 年の $41.1 \mathrm{~kW}$ 一増加した。同時期の県平均の $20.0 \mathrm{~kW}$ と比較して 非常に大規模であった。製材所の増加と規模拡大に伴い、素材需要 も大きく増加した。田辺への素材入荷量は、戦前の昭和 12 年に約 7 万 $\mathrm{m}^{3}$ であったが、昭和 30 年代前半には約 20 万 $\mathrm{m}^{3}$ まで増加し、その 内 3 割を県外産材が占めるようになった ${ }^{4), 16), 17) 。 ~}$

山長商店は、田辺の製材所が数・規模共に拡大寸る状況に応じて 自社製材所を設立し、素材生産から製材、販売まで自社で一貫して 行う体制となった。田辺に入荷する全素材のうち、約 7\%の 13,773 $\mathrm{m}^{3}$ を山長商店の自社工場で製材した。昭和 30 年代前半の田辺の平 均的な生産量である 1 工場当たり約 5 千 6 百 $\mathrm{m}^{3}{ }^{4}$ ) と比較して大規模 であったが、全体に占める割合は小さく、山長商店だけでなく地域 全体の製材所が繁栄していたことが分かる。

\section{4-2. 米材製材隆盛期（昭和 36 年 47 年)}

田辺港の米材輸入がピークであった昭和 45 年、10の大規模製材 所が米材製材へと転換し、27 の製材所（内 3 工場が大規模製材所） が国産材製材にとどまった。田辺への素材入荷量は、国産材が約 4 万 2 千 $\mathrm{m}^{3}$ に対し米材は $328,700 \mathrm{~m}^{3}$ であり、国産材の約 8 倍もの米材 が輸入されていた。輸入された米材は、10の大規模米材製材所でほ ぼ均等に分配されていた ${ }^{4), 16) 。}$

山長商店は米材製材所を設立し、米材製材に移行したグループ会 社の第一製材と共に田辺の大規模米材輸入・製材の一部を担った。 一方、採算が取れないながらも継続した国産材製材では、山長商店 は田辺に入荷する国産材の $24 \%$ を占める $10,041 \mathrm{~m}^{3}$ の素材を製材し ていた。米材と国産材を合計して、田辺へ入荷する全素材の $14 \%$ を 山長商店が製材し、田辺の製材業における山長商店が占める割合が 増加した。

\section{4-3. 米材製材低迷期（昭和 48 年 平成 10 年)}

田辺港の米材輸入量は約 7 万 $3 \mathrm{~m}^{3}$ と、最盛期の約 5 分の 1 に減 少した。田辺の国産材入荷量は約 5 万 $\mathrm{m}^{3} て ゙ 、$ 米材製材隆盛期とあま り変化はなかった。製材所は 24 工場に減少し、閉鎖した製材所の 多くは国産材製材所であった ${ }^{4), 16) 。 ~}$

山長商店は、米材素材の価格高騰や輸入量減少を受け、米材製材 
の規模を縮小した。一方、若干ではあるが、国産材製材の規模を拡 大した。製材事業全体を見ると規模縮小したものの、田辺の他製材 所の規模縮小や閉鎖により、田辺に入荷寸る素材の $28 \%$ を占める $14,754 \mathrm{~m}^{3}$ を製材するなど、田辺における山長商店が占める製材割合 が更に増加した。

\section{4-4. 国産材製材転換期（平成 11 年 ）}

田辺港の米材輸入は終了し、他地域から米材素材を移入して事業 を継続していた一部の米材製材所も全て閉鎖した。国産材製材所の 閉鎖も続き、製材所は 8 工場に減少した。田辺の国産材入荷量は、 約 3 万 5 千 $\mathrm{m}^{3}$ であった。

田辺港の米材輸入終了後も、山長商店と第一製材は他地域から移 入した素材を利用して米材製材を継続したが、採算が取れなかった ため平成 12 年に山長商店が、平成 14 年に第一製材が米材製材を終 了した。山長商店は $28,213 \mathrm{~m}^{3}$ の国産材を製材し、田辺に入荷する $80 \%$ の素材を山長商店 1 社で製材していた。山長商店とグループ会 社の第一製材を除く 6 の製材所は、小規模なものであった。数・規 模共に田辺の製材業の大部分を山長商店が担うようになった。

\section{4-5. 小結：山長商店による地域の活力低下の補完}

山長商店は、米材製材隆盛期までは自社の規模拡大によって、米 材製材低迷期以降には他社の閉鎖や規模縮小によって、田辺に占め る素材消費量の割合を増していった。特に現在は、田辺に入荷寸る ほとんどの素材を山長商店が入荷しており、小規模な製材所 6 社と グループ会社の第一製材を合わせた大規模な山長商店という構図で ある。地域の林業・木材業の活力は低下したが、山長商店が製材量 を増加させ、地域活力の低下を補完していることが明らかとなった。

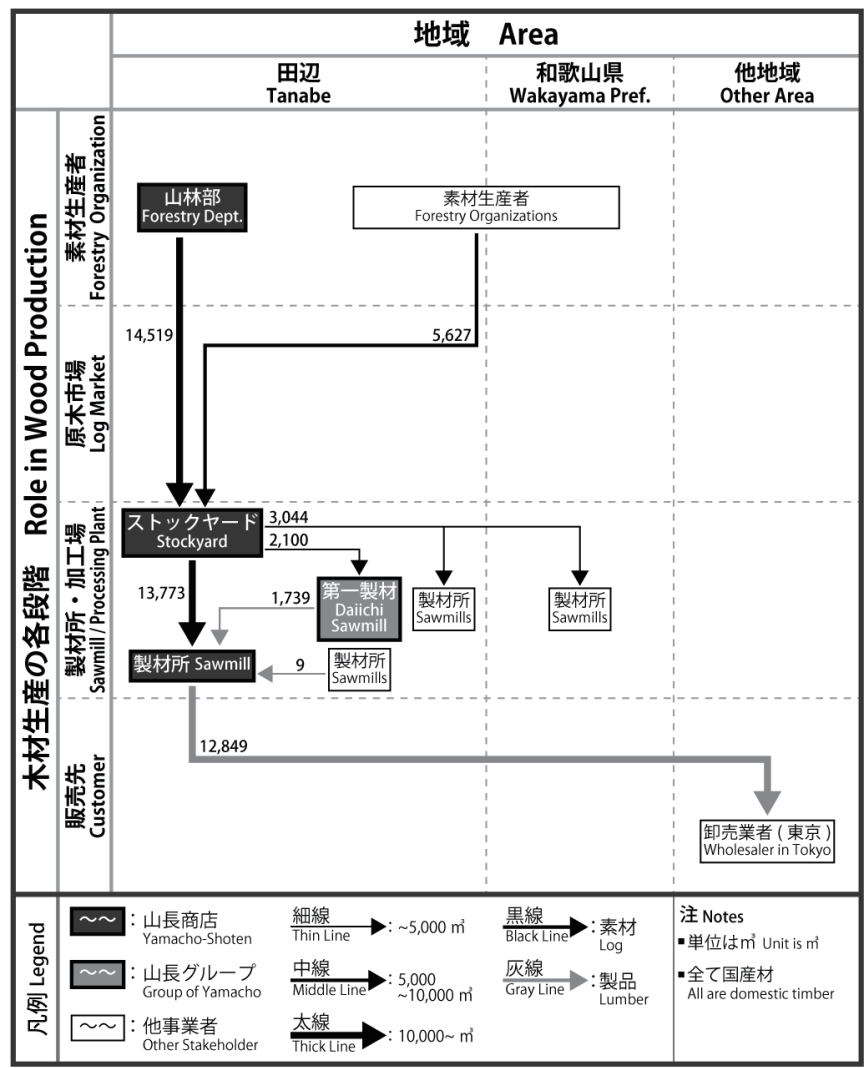

Fig.2 Wood Production Structure of Yamacho-Shoten in 1958 昭和 33 年の山長商店の木材生産構造

\section{5. 山長商店の木材生産構造の変遷}

各時期のある年における山長商店の木材生産構造を、木材生産の 業態別に素材生産者／原木市場／製材所・加工場／販売先の 4 つに 注 7)、事業者の位置寸る地域を田辺 /和歌山県 /他地域の 3 つ分類 し 注8、4つの生産段階と 3 つの地域の広がりの組み合わせにより図 化した(図 2-5)。図版の作成と分析には、山長商店と山長林業へのヒ アリング調查と、山長商店の決算書(昭和 33 年度、昭和 45 年度、平 成 7 年度、平成 30 年度) と文献 18 )を参照した。決算書は年毎に書式 が異なり、全ての取引業者を把握可能な年と不可能な年があるため、 取引先の主な地域と取引量を図版に表現した。各時期の中で対象と した年は、昭和 33 年 : 山長商店が自社製材所を設立した直後、昭和 45 年: 米材輸入のピークで田辺の製材業が栄えていた時、平成 7 年: 米材輸入停止直前かつ山長商店のプレカット事業の開始直前の過渡 期、平成 30 年 : プレカット事業が安定した最新の時期である。

対象年における木材生産構造について考察するため、以下の順に 整理をしていく。【素材生産者・原木市場】：素材生産から製材所 の素材の流れや、他素材生産者や原木市場、他製材所等との素材の 取引の過程を記す。【製材所・加工場】：製材所での製材・加工や他 製材所との取引の上で製品販売に至る過程を記す。【販売先】: 製品 販売先の地域や業態の特性を記す。【木材生産構造】: 以上の 3 つの 観点から、各時期の山長商店の木材生産構造の特徵を総合的にまと める。

\section{5-1. 国産材製材発展期（昭和 33 年、図 2)}

【素材生産者・原木市場】田辺や県内の他素材生産者からの購入が $5,627 \mathrm{~m}^{3}$ であったのに対し、山長商店山林部による素材生産が全体 の約 7 割を占める $14,519 \mathrm{~m}^{3}$ と、自社による素材生産が主な素材供 給源であった。また、資力に乏しく自ら山林購入や素材生産、遠方 からの素材購入を行うことができない田辺や県内の小規模製材所へ 山長商店に入荷した素材全体の約 $15 \%$ ある $3,044 \mathrm{~m}^{3}$ の素材を販売 した。

【製材所・加工場】昭和 33 年、山長商店は経営参画する第一製材か ら高度な技術を学び、自社製材所を設立した。第一製材へ依頼して $2,100 \mathrm{~m}^{3}$ の素材を製材させたのに対し、自社製材所で $13,773 \mathrm{~m}^{3}$ の素 材を製材しており、自社製材所による製材が主となった注9)。

【販売先】東京都の深川市場を中心に、東京や関東の卸売業者一 $12,849 \mathrm{~m}^{3}$ の製品を販売した。同一規格の製品を大量生産・販売し、 地元需要を圧迫しないように配慮していたため、地元工務店や大工 への小売は行わなかった注10)

【木材生産構造】戦後復興や朝鮮戦争特需を背景に、多数の製材所 が設立された田辺において、山長商店は自社製材所を設立した。山 長商店の木材生産構造は、主に自社で生産した素材を製材し、東京 や関東の卸売業者へ販売するものであった。

5-2. 米材製材隆盛期（昭和 45 年、図 3)

【素材生産者・原木市場】昭和 36 年に始まった田辺港の米材輸入 はピークを迎え、山長商店は国産材 $16,108 \mathrm{~m}^{3}$ に対し、約 2.7 倍の米 材 $43,588 \mathrm{~m}^{3}$ を入荷していた。山長商店山林部による素材生産量は 前時期とほぼ同じであったが、他素材生産者からの素材購入量は $5,627 \mathrm{~m}^{3}$ から約 3 分の 1 の $1,837 \mathrm{~m}^{3}$ 一減少した。また、最高級の素 材は自社で製材するよりも素材のまま販売する方が利益を上げられ たため注 11)、尾熟や熊野川流域の所有山林を拡大し、檜の良材は尾 


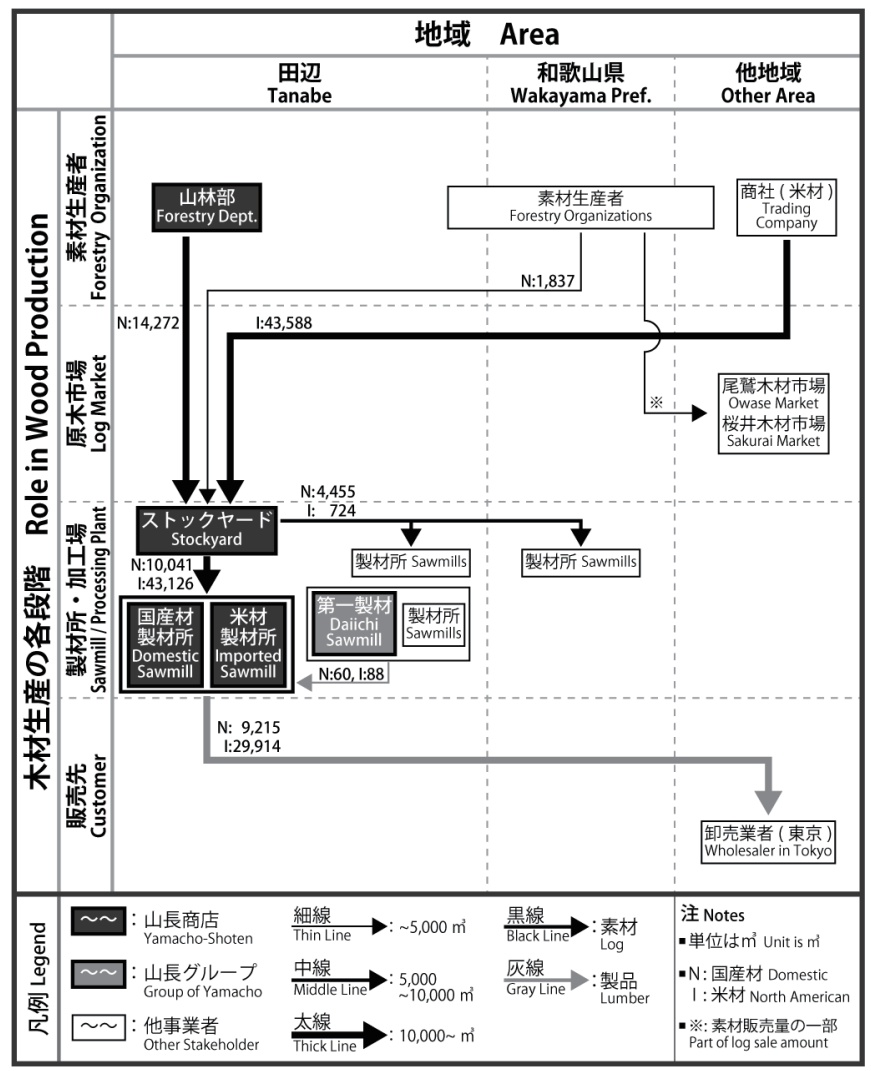

Fig. 3 Wood Production Structure of Yamacho-Shoten in 1970 昭和 45 年の山長商店の木材生産構造

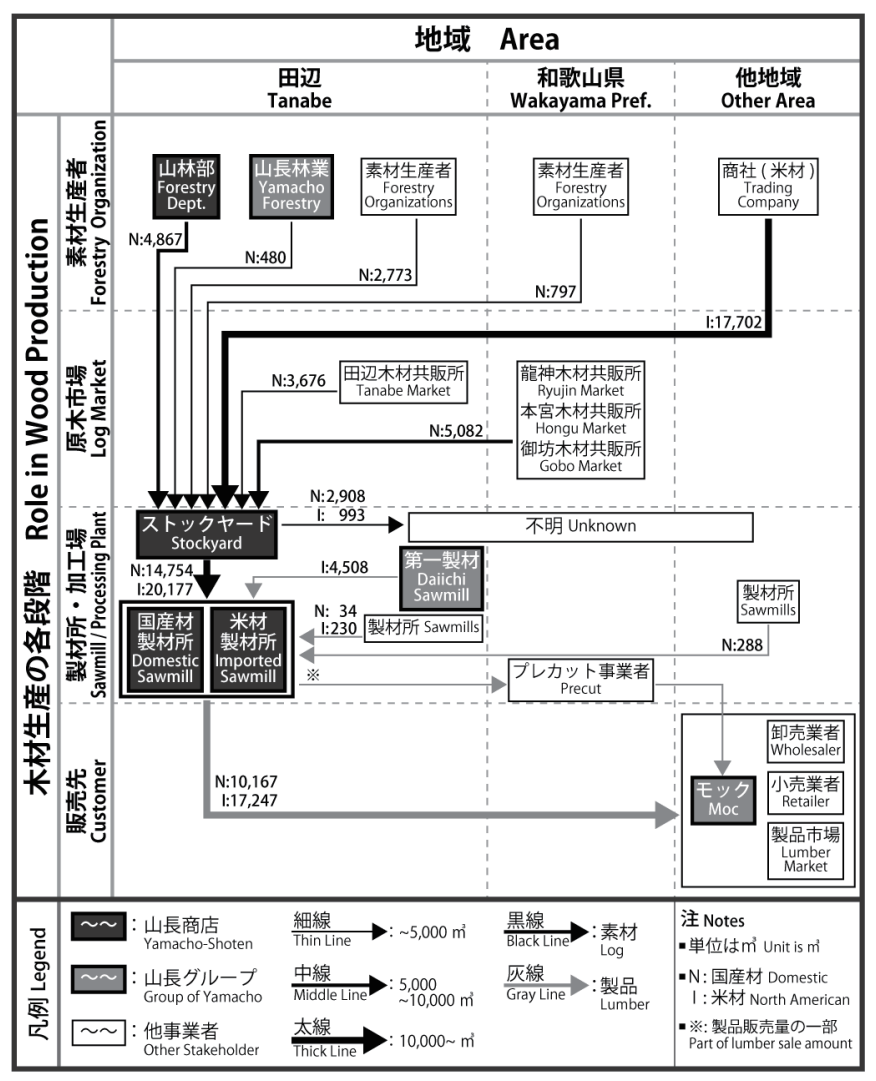

Fig.4 Wood Production Structure of Yamacho-Shoten in 1995 平成 7 年の山長商店の木材生産構造
熟木材市場へ、杉の良材は桜井木材市場へ販売した。国産材仕入量 が減少した一方、地域の他製材所や原木市場への素材販売量は $3,044 \mathrm{~m}^{3}$ から $4,455 \mathrm{~m}^{3}$ へ増加したため、自社で製材する国産材の量 は 13,773 mら $10,041 \mathrm{~m}^{3}$ 減少した。

【製材所・加工場】昭和 36 年の田辺港の米材輸入開始とともに米 材製材を始め、昭和 43 年に米材専門製材所を設立した。国産材 $10,041 \mathrm{~m}^{3}$ に対し、約 4.3 倍の米材 $43,126 \mathrm{~m}^{3}$ を製材するなど、主生 産品目が米材製品へと移行した。一方、山林業者として広大な山林 を持つ山長商店は、国産材素材の価格の高騰を受け採算性が著しく 低下したにもかかわらず国産材製材を継続した。大規模米材製材所 となった第一製材は自ら素材を購入し製品を販売したため、山長商 店への販売はほとんどなかった。

【販売先】国産材製品販売量は前時期の $12,849 \mathrm{~m}^{3}$ から $9,215 \mathrm{~m}^{3}$ 一 減少したが、米材製品販売量 $29,914 \mathrm{~m}^{3}$ を加え、全体の製品販売量は 約 3 倍の $39,129 \mathrm{~m}^{3}$ へきく増加した。前時期と同様に、東京・関 東の卸売業者への販売が主であった。

【木材生産構造】田辺港の米材輸入を端緒として山長商店の米材製 材が始まり、製材業を中心に事業が大規模化した。山長商店の木材 生産構造は、自社で生産した素材の製材を基盤として継続しつつ、 大量の米材素材を利用した製材を行い、東京や関東の卸売業者へ販 売する二重構造であった。

5-3. 米材製材低迷期（平成 7 年、図 4)

【素材生産者・原木市場】田辺港の米材輸入量減少に伴い、山長商 店の米材入荷量は、最盛期である前時期の $43,588 \mathrm{~m}^{3}$ から半分以下 の $17,702 \mathrm{~m}^{3}$ へ大きく減少した。国産材の自社における素材生産量 は、林業労働者の賃金上昇を受けて湦 ${ }^{12)}$ 、前時期の $14,272 \mathrm{~m}^{3}$ から約 3 分の 1 の $4,867 \mathrm{~m}^{3}$ 一激減した。昭和 48 年に設立された山長林業 は当時、間伐や保育が主業務であり、素材生産量は $480 \mathrm{~m}^{3}$ と少なか った。自社の素材生産量や米材入荷量の減少を補うように、田辺や 県内の他素材生産者からの素材購入を前時期の $1,837 \mathrm{~m}^{3}$ から約 2 倍 の $3,570 \mathrm{~m}^{3}$ 一増加させ、さらに、田辺木材共販所、龍神木材共販所、 本宮木材共販所、御坊木材共販所から $8,758 \mathrm{~m}^{3}$ の素材購入を行った。 また、自社製材所の素材を優先したため、他製材所や原木市場への 素材販売量が前時期の $5,179 \mathrm{~m}^{3}$ から $3,901 \mathrm{~m}^{3}$ 一減少した。

【製材所·加工場】製材所への米材素材投入量は前時期の $43,126 \mathrm{~m}^{3}$ から半分以下の $20,177 \mathrm{~m}^{3}$ へ大幅に減少したのに対し、国産材投入 量は前時期の $10,041 \mathrm{~m}^{3}$ から $14,754 \mathrm{~m}^{3}$ へ増加した。平成元年に山長 グループの一社となった第一製材は、独自に素材仕入や製材を行い、 $4,508 \mathrm{~m}^{3}$ の米材製品を山長商店一販売した。

【販売先】販売量は、国産材製品は 9,215 $\mathrm{m}^{3}$ から $10,167 \mathrm{~m}^{3}$ 一微増 にとどまったのに対し、米材製品は $29,914 \mathrm{~m}^{3}$ から $17,247 \mathrm{~m}^{3}$ 一減少 した。首都圈のドーナツ化現象による東京郊外への木材需要の移動 を受け、グループ会社のモック注13)を中心に東京郊外の小売業者へ 販売先を転換し始めた。県内プレカット業者への一部製品の委託加 工を始め、この事業によりプレカット材の販売先確保の見込みが立 ち、自社プレカット工場設立のきっかけとなった。

【木材生産構造】米材素材の入荷量減少と自社による素材生産量の 減少を補うため、田辺や県内の素材生産者や原木市場からの素材購 入が増加し、販売先も卸売業者のみから多角的な販売へと変化した。 山長商店の木材生産構造は、購入・販売共に拡散したものとなった。 


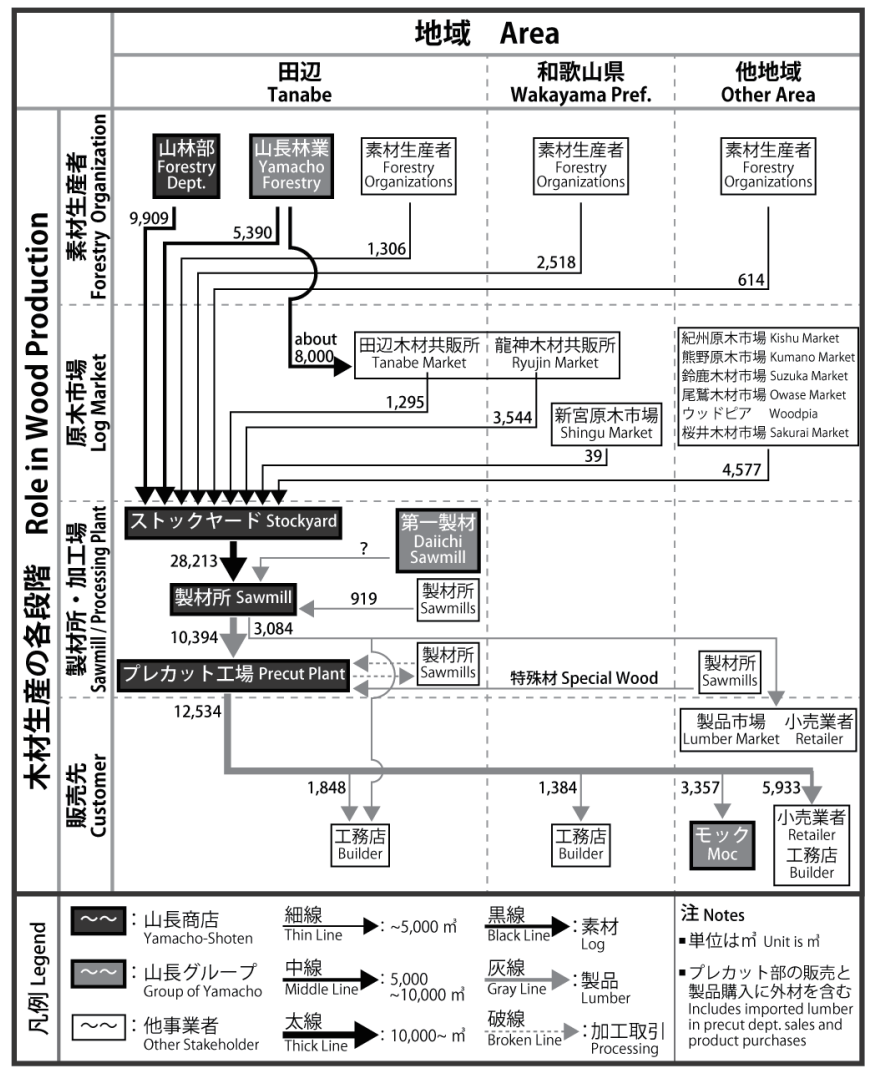

Fig. 5 Wood Production Structure of Yamacho-Shoten in 2018 平成 30 年の山長商店の木材生産構造

5-4. 国産材製材転換期（平成 30 年、図 5)

【素材生産者・原木市場】米材素材の入荷量はゼロとなった。一方、 国産材は、山長商店山林部、他素材生産者、原木市場全てからの入 荷が増加した。保育から素材生産に主業務を移行した山長林業の素 材生産量は $480 \mathrm{~m}^{3}$ から約 $13,390 \mathrm{~m}^{3}$ 一大きく増加した。より良質な 製品を生産するため、山長林業の生産する比較的低質な約 8 千 $\mathrm{m}^{3} の$ 素材を市場に販売し、代わって良質な素材を市場から購入した。原 木市場では、田辺や県内から $4,878 \mathrm{~m}^{3}$ の素材を仕入れる一方、三重 県を中心とした県外からの購入が $4,577 \mathrm{~m}^{3}$ 増加し、県内でほぼ完 結していた国産材入荷圈が、三重県・奈良県へと拡大した。

【製材所·加工場】製材所一の国産材投入量は $14,754 \mathrm{~m}^{3}$ から約 2 倍 の $28,213 \mathrm{~m}^{3}$ へ増加した。しかし、詳細は不明であるが歩留まりが悪 化し、国産材製品販売は 10,167 $\mathrm{m}^{3}$ から $13,478 \mathrm{~m}^{3}$ 一増加するにとど まった。第一製材も米材製材から撤退し、現在は板専門の工場とし て山長商店と役割分担して操業している注 14$)$ 。製品の付加価值を高 め、大工や工務店に直接販売するために、販売する製品全体の約 8 割の製品をプレカット工場で加工している。工務店へ小売をするた めに家 1 軒分の建材が必要なため、他製材所からの製品購入が増加 した。例えば、山長商店の隣に位置する製材所から山長商店が檜の 役物を購入する事例が確認されている注 15)。一方、地域で生産でき

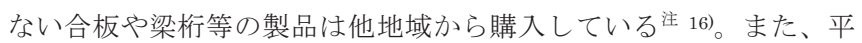
成 10 年の「住宅品質確保法」の制定と木造住宅のプレカット材利 用率の上昇により、乾燥済プレカット材の需要が非常に大きくなっ ており、田辺木材協同組合に参加する他製材所の製品を山長商店が 乾燥・プレカット加工する関係性が構築された。
【販売先】プレカット製品は小売業者や木材流通の末端である工務 店へ直接販売するため、プレカット材が製材・加工の中心となると ともに東京都心への販売が激減し、住宅需要のある東京郊外一の販 売が増加した。関西や他地域一の販売も拡大した。製品の約 $20 \%$ は 関東の小売業者や製品市場一販売されていたが、利益向上のため多 くの製品がプレカット工場で加工、販売された。また、他地元製材 所の減少により、地元への販売量も増加した。

【木材生産構造】自社による素材生産量を増加させつつも、県内外 から広く素材を仕入れるようになり、販売先もより広域化した。ま た、プレカット工場や乾燥機等の設備は、地域の製材所との接点を 増加させた。山長商店の木材生産構造は、素材仕入、製品生産、製 品販売において一貫生産を保ちながらも、他事業者との関わり合い の中で多角化したものとなった。

\section{5-5. 小結 : 山長商店の木材生産の各段階における変遷}

以上より、山長商店の木材生産構造の変遷を、木材生産の段階每 にまとめる。

【素材生産者·原木市場: 自社生産の継続と仕入元の広域化·多様化】

山長商店の林業と素材生産・供給の変遷において重要なのは、自 社生産を基盤として継続しつつ、素材仕入の広域化と多様化を行っ たことである。国産材製材発展期においては、自社による生産と田 辺又は県内の他素材生産者からの仕入のみであったが、時期を追う 毎に米材取扱商社や山長林業、原木市場、県外素材生産者等との取 引を構築し、仕入元を広域化・多様化させている。

\section{【製材所・加工場：素材入荷の変化と事業者間連携の増加】}

山長商店は経済状況や需要の変化に合わせて米材素材の入荷量を 変化させ、米材専門製材所の設立や第一製材との連携を行った。一 方、国産材製品の生産量は、常に 1 万 $\mathrm{m}^{3}$ 前後を保ってきた。山長 商店の山林資源を活用寸るための国産材製材が、技術の継承に繋が り、米材輸入が終了し国産材転換が叶わなかった多くの大規模製材 所の中で生き残りを果たした。また、乾燥プレカット材の需要に対 応し設備投資を行い、プレカット業に進出した。同一製品を大量に 販売する卸売から、家 1 軒分の建材を販売する小売へ販売形態を 移行したため、多様な製品が必要となり、他製材所からの製品購入 が増加している。

\section{【販売先：関東中心／卸売から小売へ】}

販売先は、常に需要の多い東京・関東が中心であるが、販売先の 業態や地域が変化している。米材製材隆盛期までは、東京の卸売業 者への販売が主であった。ドーナツ化現象が発生した米材製材低迷 期には、グループ会社のモックを中心に、東京郊外の小売需要に対 する販売が増加した。プレカット事業を中心に行うようになった国 産材製材転換期には、卸売業者への販売はほとんどなくなり、大工 や工務店への直接販売が主となった。また、県内の他製材所の衰退 から、田辺や県内一の製品販売も増加した。

\section{【木材生産構造：自社一貫生産と多様なネットワークの構築】}

山長商店が生み出す木材生産構造の特徴は、自社を中心として地 域内で素材生産や仕入を行い、生産した製品を東京や関東へ販売す る点にある。この基本構造の上に、安価な米材を利用した大規模米 材製材や、原木市場を利用した良質な製品の生産、プレカット事業 による販売先の転換等、他事業者との連関の中で木材生産構造を変 化させ、事業を継続・発展させてきた。 


\section{6. 考察：山長商店の木材生産構造による林業・木材業産地の形成}

前章までで、山長商店の林業・木材業が地域の事業者との取引に よるネットワークの中で継続・発展してきたことが明らかになった。 そのうえで、山長商店は事業者であるため自社の利益を追求するの が第一義であるが、長年事業を継続する上で地域の他事業者への配 慮や共生関係があったと考えられる。本章では、 4 章と 5 章の分析 を基に、山長商店を中心とした田辺全体の木材生産構造の中で生ま れる相互関係について考察する。

\section{6-1. 素材生産者 一その 1：地域山林資源の活用一}

山長商店は、各時期において自社林の伐採以外にも他素材生産者 から立木の購入や伐採をした。山長商店にとっては、製材所の素材 不足を補うための生産や購入であったが、地域の山林所有者や山林 業者にとっては、山林資源の有効活用へ繋がった。

\section{6-2. 素材生産者 一その 2：地域の製材所への素材供給一}

山長商店は、地域の需要に対して不足する素材を供給する役割を 常に担ってきた。地域に原木市場が出現した米材製材隆盛期までは、 他製材所への直接販売によって素材を供給し、市場設立後の米材製 材低迷期以降は、原木市場に販売された山長商店の素材を間接的に 地域の他製材所が購入している。これらは、自ら山林購入や素材生 産を行うことのできない、資力にそしい小規模製材所が今日まで生 き残ることのできた要因の一つである。山長商店にとっては高品質 な製品を生産するため比較的低質な素材を販売する取引であったが、 地域製材所にとっては貴重な素材確保の源となってきた。

\section{6-3. 原木市場 一素材供給者であり購入者一}

山長商店は高品質な製品を生産するために、比較的低質な素材を 原木市場へ販売し、逆に、良質な素材を市場から購入している。山 長商店にとっては高品質な製品を生産するための取引が、原木市場 にとっては素材の十分な仕入元と大口販売先の確保に繋がっている。 素材確保に苦労する原木市場が多く、御坊木材共販所は競りを終了 するほど素材が不足する状況で注 17)、山長商店との取引は経済循環 を起こす契機を与え、原木市場が存続する要因の 1 つとなっている。

\section{6-4. 製材所・加工場 一その1：製品購入一}

製材所設立当時から、特殊材等を地域の事業者から購入する繋が りがあった。現在はプレカットを製材・加工業の中心に据え、家 1 軒分の木材を小売業者や工務店に販売する必要があるため、主構造 材(柱等)や板材以外の、大量生産できない製品の地域の他業者から の購入が増加している。山長商店にとっては家 1 軒分の木材を揃え るための製品購入が、地域の製材所にとっては販売先の確保につな がっている。一方、地域内に製造者が存在しない合板等は、地域外 から購入している。

\section{6-5. 製材所・加工場 一その 2 ：製品の二次加エ一}

プレカット工場と乾燥機を所有する山長商店を中心に、地域製材 所との連携関係が生まれている。乾燥済プレカット材の需要に対 し、小規模製材所は高価なプレカット機や乾燥機を購入することが できないため、田辺木材協同組合に所属する他製材所は山長商店に 木材の乾燥・プレカット加工をしてもらい、工務店に販売する構造 となっている。山長商店にとって小規模な加工依頼は利益が少ない が、地域の他事業者が生き残るために加工を請け負っている注 10)。 当地方において数少ない乾燥機とプレカット工場を持つ山長商店 は、製材・加工の中心的役割を担っている。

\section{6-6. 販売先 一地元需要の保護一}

山長商店は、米材製材隆盛期までは大量生産製品を大ロットで販 売可能な東京・関東を中心に販売を行ってきた。山長商店にとって は大口販売するための東京・関東への販売が、地域の他製材所にと っては地元の小口需要の競合を避けることに繋がった。山長商店は、 小規模製材所の需要を奪わないように意識的に地元向けの販売を行 わなかったが、国産材転換期には地域製材所の減少を理由に、田辺

や県内の工務店へのプレカット製品の販売も行っている。

\section{6-7. 小結：山長商店と田辺の木材生産構造が生み出す相互補完}

以上より、山長商店の木材生産構造が、素材生産や製材、加工、 販売の面で相互補完の関係性を構築してきたと考えられる。山長商 店は一貫生産であるがゆえに、木材生産の各段階において他社との 取引が必要となる。地域内の素材生産者、原木市場、製材所、販売 先のす心゙ての事業者の生産活動が活発であれば、山長商店は取引先 を地域内に容易に確保することができる。良質な紀州産材を継続し て生産するために、山長商店は地域事業者との意識的な共存を図っ てきたと考えられる注 10)。

\section{7. まとめ・展望}

以上の結果から、田辺の林業・木材業の盛衰の中で、山長商店が 地域の山林資源や事業者と関わり合いながら林業・木材業を持続さ せてきた実態と、地域における役割について明らかにした。

\section{7-1. まとめ}

山長商店の林業・木材業が継続してきた大きな要因の一つに、一 貫生産体制が持つ柔軟性が挙げられる。素材生産の基盤があるから こそ製材業において米材製材やプレカット事業等に進出寸ることが でき、製材業があるからこそ経済状況等を考慮しながら素材供給元 を自社や市場、他事業者と変化させることができた。

また、自社の山林資源を活用し、製材、加工、販売を行う山長商 店の一貫生産体制の過程で、地域の他事業者と相互補完する関係が 存在することが明らかになった。一貫生産体制の中で、自社で行う ことのできない部分を地域の他事業者に依頼し補完する必要がある ため生まれた関係性である。地域の事業者との取引によるネットワ 一クの多様化により、山長商店の木材生産構造における素材や製品 の仕入・販売の選択肢は増加し、地域の他事業者にとっては安定し た取引先の確保に繋がっている。

さらに、山長商店自らが素材供給源として地域製材所の継続を底 支えする役割を果たしてきた。慢性的な素材不足から米材輸入が始 まった田辺において、豊富な素材供給は製材業拡大の重要な要因で あった。現在に至るまで山長商店は素材確保に苦労する原木市場に 素材を販売し、地域製材所への直接販売から市場経由に形態を变え ながら、地域製材所の素材供給源の役割を果たしている。

山長商店は、山林を活用した素材供給と製材、加工、販売までを 行う一貫生産体制によって、地域の他事業者と相互補完の関係性を 構築し、地域の他事業者と共に林業・木材業産地を形成してきたこ とが分かった。

\section{7-2. 展望}

これまでの山長商店の木材生産構造による林業・木材業産地の形 成は、自社工場やグループ会社の設立により、他事業者とのネット ワークを構築し、他事業者の継続を担保するものであった。現在の 
田辺の木材生産構造を概観すると、山長商店に依存する傾向が見ら れる。そこで、山長商店の木材生産構造を補完するような事業者の 設立が考えられる。例えば、山長商店では生産していない合板や、 多様な規格を生産することの難しい梁桁等の特殊材に特化した工場 の設立が考えられる。田辺では、日本唯一の山林保育専門の民間会 社が平成 28 年に設立され、山長林業が保育から生産へ軸足を移行 した業務を補完するネットワーク更新の萌芽が既に見られる注 18)。 他事業者の進出により、山長商店を核としつつも多様な事業者によ る相互補完的なネットワークを構築することが、山長商店を含む地 域の林業・木材業に関わる事業者の継続性をより高めると考える。

\section{謝辞}

本稿執筆にあたり、田辺や和歌山県の林業・木材業にかかわる多 くの方々にご協力いただきました。特に山長商店、山長林業の方々 には、長時間にわたるヒアリングや資料提供に快くご協力いただき ました。記して御礼申し上げます。

尚、本研究は、日本学術振興会特別研究員奨励費「紀伊半島にお ける木材生産の圈域化計画と大災害への木造仮設住宅供給システム の構築」(課題番号 : 21J10995)の助成を受けたものである。

\section{参考文献}

1)Ishida Shuichi and Furusaka Shuzo : Comparative Study among Some Regions about the Drop Shipment-Type Wooden Housing Projects Utilizing Locally-Produced Lumbers -In Search of Project Optimization in Kyoto-, Journal of Architecture and Planning (Transactions of AIJ), Vol.73, No.631, pp.1947-1952, 2008. 9 (in Japanese)

石田修一, 古阪秀三：地域産材を活用した木造住宅生産プロジェクトの地 域間比較 - 京都におけるプロジェクト最適化の探求-, 日本建築学会計画 系論文集, 第 73 巻, 第 631 号, pp.1947-1952, 2008. 9

2)Shirai Yuko : A Study on The Timber Distribution System and the Balance of the Timber Supply and demand in the Nagara River Basin Region of the Gifu Prefecture -The sustainable development of the timber resources due to the local industries-, Journal of Environment and Engineering (Transactions of AIJ), No.605, pp.155-162, 2006. 7 (in Japanese)

白井裕子：岐阜県長良川流域における木材流通と木材需給の均衡に関す る調査研究 -地域産業を通じた森林資源の持続的保全-, 日本建築学会環境 系論文集，第 605 号, pp.155-162, 2006. 7

3)Adachi Tetsu, Yamazaki Yoshito and Nakano Takashi : The Utility of Small/Medium Scale System of Wood Distribution and Marketing on the Value Improvement of Planted Forest -From the point of view of problem solving and substituting for advantage of conventional wood distribution-, Journal of Architecture and Planning (Transactions of AIJ), Vol.81, No.727, pp.1939-1948, 2016. 9 (in Japanese)

足立徹, 山崎義人, 中野崇志：人工林の価值向上に対する中小規模な木材 の流通・販売システムの有用性 -従来型の木材流通における課題の解決と 利点の代替の観点から-, 日本建築学会計画系論文集, 第 81 巻, 第 727 号, pp.1939-1948, 2016. 9

4)Federation of Wakayama Prefectural Lumber Cooperative Association : Wakayama Prefecture Wood History, Federation of Wakayama Prefectural Lumber Cooperative Association, 1993 和歌山県木材協同組合連合会：和歌山県木材史, 和歌山県木材協同組合連 合会, 1993

5)Horio Sakuhito and Jinnai Hidenobu : Growth of Water-Powered Industrial City, Kiryu Right Before Japan's Industrial Revolution, Journal of Architecture and Planning (Transactions of AIJ), Vol.82, No.737, pp.1839-1846, 2017.7 (in Japanese)

堀尾作人, 陣内秀信 : 産業革命前における水力産業都市・桐生の形成, 日 本建築学会計画系論文集, 第 82 巻, 第 737 号, pp.1839-1846, 2017. 7

6)Okuma Mizuki and Nohara Taku : A Study on the Network Based on the
Industrial Co-operation in the Residential-Industrial Mixed Use Area Focused on the Residential-Industrial Mixed Use Area in Omori Minami Area in Ota-ku-, Journal of the City Planning Institute of Japan, Vol.46, No.3, pp.493-498, 2011 (in Japanese)

大熊瑞樹, 野原卓：住工共存地域における工場連携を基盤とした地域ネッ トワークの重層性に関する研究 -大田区大森南における住工共存地区に着 目して一, 都市計画論文集, Vol.46, No.3, pp.493-498, 2011

7)Hamada Megumi, Nakajima Naoto and Nishimura Yukio : Spatial Characteristics of Residential-Industrial Mixed-Use Area in Northern Taito-Ward from the Viewpoint of Leather Industry Buildings -A Study on the Fact and Inheritance of Urban Residential-Industrial Mixed-Use Area from the Viewpoint of Regional-Industrial Structure Part2-, Journal of Architecture and Planning (Transactions of AIJ), Vol.84, No.762, pp.1739-1746, 2019. 8 (in Japanese)

演田愛, 中島直人，西村幸夫：皮革関連産業事業所建築から見た台東区北 部地域の職住混在空間特性 地域産業空間構造から見た都市部職住混在空 間の実態と継承に関する研究その 2 , 日本建築学会計画系論文集, 第 84 巻, 第 762 号, pp.1739-1746, 2019. 8

8)Hagino Toshio and Sakamoto Kazutoshi : Characteristics and Trend of Saw-mill Industries in Kinan Area, Forest Economy, Vol.11, No.9, pp.112,1958

萩野敏雄, 坂本一敏：紀南製材地帯の性格と動き, 林業経済, 11 巻, 9 号,pp.1-12, 1958

9)Arimizu Tsutomu : Structure of Shingu and Tanabe Timber Market Introduction-, Forest Economy, Vol.11, No.12, pp.20-34, 1958

有水疆：新宮・田辺木材市場の構造 -序論-, 林業経済, 11 巻, 12 号,pp.2034, 1958

10)Nomura Isamu : Structure of Timber Markets in Wakayama District, Forest Economy, Vol.12, No.3, pp.32-37, 1959

野村勇：和歌山木材市場の性格と構造, 林業経済, 12 巻, 3 号,pp.32-37, 1959

11)Ariki Sumiyoshi : Ryujin Forestry Transformation Process - Focused on Forestry Management Behavior after 1965-, Journal of Forest Economics, No.95, pp.6-14, 1979

有木純善 : 龍神林業の変容過程 -昭和 40 年以降における林業経営の行動 様式を中心にして-, 林業経済研究, 95 号,pp.6-14, 1979

12)Hata Tateki : Recent Development of Domestic Log Sawmills -Mainly Based on Case Examples in Kumamoto and Oita Model Areas of a Governmental Forestry and Forest Industry Promotion Project, Journal of Forest Economics, Vol.57, No.3, pp.61-67, 2011

幡建樹：国産材製材工場の新たな展開 -新生産システム熊本・大分両モデ ル地域を中心として-, 林業経済研究, 57 巻, 3 号,pp.61-67, 2011

13)Ochi Shunsuke and Fujikake Ichiro : Log Purchasing Strategy of Sawmill Factories and Variety of Log Distribution in Log-AuctionDepended Area -A Case Study of Hita, Oita, Journal of Forest Economics, Vol.59, No.2, pp.1-10, 2013

大地俊介, 藤掛一郎：市売依存地域における製材工場の素材仕入戦略と 素材流通の多様化 -大分県日田製材産地の事例-, 林業経済研究, 59 巻, 2 号,pp.1-10, 2013

14)Handa Ryoichi : Japan's Mountain Villages, Forestry and Forest Policy as Social Common Capital -From the Historical Perspective of Regional Organizations-, Forest Economy, Vol.67, No.6, pp.1-18, 2014 半田良一：社会的共通資本としての山村・林業・林政 -とくに地域組織論 の観点から-, 林業経済, 67 巻, 6 号,pp.1-18, 2014

15)Tsukura Mayuko, Goto Haruhiko, Sato Hirosuke and Yamamura Shu : Restructure of Basin Area by Social Network -In case of wood industry in basin of Tenryugawa-, Journal of Architecture and Planning (Transactions of AIJ), Vol.77, No.673, pp.593-600, 2012. 3 (in Japanese) 津倉真優子, 後藤春彦, 佐藤宏亮, 山村崇 : 社会的ネットワークによる流 域圈の再構築 -天竜川流域圈の材木産業を事例として-, 日本建築学会計画 系論文集, 第 77 巻, 第 673 号, pp.593-600, 2012.3

16)Tanabe Lumber Cooperative Association : Living in a Tree -Kishu Tanabe Wood History-, Tanabe Lumber Cooperative Association, 2003 田辺木材協同組合：木に生きる - 紀州田辺木材史-, 田辺木材協同組合, 2003

17)Handa Ryoichi : Japan's Forestry Issues -Forestry Development 
Structure in the Kii Peninsula-, Minervashobo, 1979

半田良一：日本の林業問題 -紀伊半島における林業の展開構造-, ミネル

ヴァ書房, 1979

18)Living with a Wood : Japan Forest Products Journal, 2020

木と共に生きて：日刊木材新聞, 2020

注

注 1)本論文において、「林業」は植林から保育、山林購入、切り出し等の素 材生産過程に関わる全業種、「木材業」は素材を製材・加工し製品を生産す る業種と定義する。

注 2)林野庁：令和 2 年度森林・林業白書.「林業の 6 次産業化」は P148、 「顔の見える関係」はP 21,176 等を参照した。

注 3)Good Design Award : https://www.g-mark.org/award/describe/40532 を参照した。

注 4)文献 18)に記載した日刊木材新聞の連載であり、令和 2 年 2 月 8 日 8 月 8 日まで計 24 回掲載された。

注 5)ウッドショックとは、米国の自然保護運動に始まる丸太輸出規制により 米材素材の価格が 2 倍以上に高騰した現象である。

注 6)山長商店へのヒアリング調査と、文献 18)を参考にした。

注 7)文献 2)を参考に業態を分類した。山長グループの木材生産が、原木市場 を介さずに直接素材生産から製材一繋がっている特徴を示すため、原木市 場を含む 4 分類とした。

注 8)田辺木材共販所は、現在は移転し西牟婁郡上富田町に位置するが、本論 文では田辺に位置するものとして扱う。

注 9)山長商店は第一製材の経営に参加し、製材を第一製材に依頼して製品を 生産していた。製材需要の増加から第一製材が独自に素材仕入と製品の生 産・販売を行うようになり、山長商店からの依頼が後回しにされるように なったため、山長商店は自社製材所を設立するに至った。

注 10）山長商店へのヒアリングより、地域の他製材所と共存し、製材・加工 に関わる大規模な設備を持つ山長商店が地域の他製材所に貢献寸ることが、 山長商店の方針であることを確認した。

注 11)山長商店へのヒアリングより確認したが、価格差や販売量のデータは 得られなかった。

注 12)山長商店へのヒアリングより確認した。

注 13)昭和 47 年に設立したグループ会社の紀和木材(株)が、平成 2 年にモッ ク(株)へと社名を変更した。モック(株)は埼玉県に位置し、山長グループの 販売部門を担う。

注 14)第一製材の製材量は不明であった。

注 15)D 製材へのヒアリングより確認した。

注 16)例えば、合板生産工場は田辺や県内に存在しないため、大阪府等の県外 の事業者から購入している。梁桁は、自社でJAS 認証を取得した杉平角を 可能な限り利用しているが、規格寸法が柱角と比較して多様でありストッ クが困難であるため、米材梁や集成材梁を広島県等の県外の事業者から購 入している。

注 17)山長商店、田辺木材共販所、龍神木材共販所へのヒアリングより確認し た。

注 18)山長商店へのヒアリングより確認した。会社 HP は以下の通りである。 http://nakagawa-forestry.com/ 


\section{FORMATION OF THE AREA OF FORESTRY AND WOOD INDUSTRY IN THE REGION FROM THE VIEWPOINT OF TRANSITION OF WOOD PRODUCTION STRUCTURE}

Through consideration of business relationships between businesses centered on Yamacho-Shoten in Tanabe, Wakayama Prefecture

$$
\begin{gathered}
\text { Kazunori HAYASHI }{ }^{* 1}, \text { Motoki SHIMODA }{ }^{* 2}, \text { Mina KOJIMA }^{* 3}, \\
\text { Shigeki MATSUBARA }{ }^{* 4} \text { and Michihiro KITA }{ }^{* 5}
\end{gathered}
$$

\footnotetext{
${ }^{*}$ Grad. Student, Division of Global Architecture, Graduate School of Engineering, Osaka University, JSPS Research Fellow (DC), M.Eng. *2 Junior Assoc. Prof., Faculty of Architecture and Arts, Otemae University, Dr.Arts Creative.

* 3 Assist. Prof., Division of Global Architecture, Graduate School of Engineering, Osaka University, Dr.Eng.

* 4 Assoc. Prof., Division of Global Architecture, Graduate School of Engineering, Osaka University, Dr.Eng.

${ }^{*}{ }^{5}$ Prof., Division of Global Architecture, Graduate School of Engineering, Osaka University, Dr.Eng.
}

The purpose of this study is to clarify the formation of the forestry and wood industry area in the region from the viewpoint of transition of the wood production structure through consideration of business relationships between businesses centered on Yamacho-Shoten in Tanabe, Wakayama Prefecture.

In order to analyze the characteristics of the transition of Yamacho-Shoten and Tanabe's forestry and wood industries, we divide them into four periods.

$<1$ st period : Domestic Lumber Development Period $>$ The wood production structure of Yamacho-Shoten was mainly to saw the log produced in-house and sell them to wholesalers in Tokyo and Kanto.

$<2$ nd period : North American Lumber Prosperity Period $>$ The wood production structure of Yamacho-Shoten became a double structure of domestic lumber produced in-house and large-scale North American lumber.

$<3$ rd period : North American Lumber Stagnation Period> The wood production structure of Yamacho-Shoten became extensive spread due to an increase in transactions with other businesses.

$<4$ th period : Domestic Lumber Turning Period> The wood production structure of Yamacho-Shoten was diversified in relation to other businesses while maintaining the integrated wood production system of foresting, sawing, processing, and selling of the products.

From the analysis above, it was clarified that Yamacho-Shoten has consideration for other businesses and that there are symbiotic relationships from the viewpoint of each category of forestry organization, log market, sawmill, processing plant and customer in wood production structure of Yamacho-Shoten.

$<$ Forestry Organization> Yamacho-Shoten's log production and sales led to the utilization of the local forest resources and supplied the necessary amount of the log to local sawmills.

$<$ Log Market> Transactions of producing high-quality lumber in Yamacho-Shoten triggered an economic cycle in the markets.

$<$ Sawmill and Processing Plant> Yamacho-Shoten created a relationship in which it purchases the products from the local sawmills and receives processing consignments.

$<$ Customer $>$ Yamacho-Shoten sold its products mainly to Tokyo and Kanto in order to avoid competing with the local saw mills.

As a result, it was found that Yamacho-Shoten has built a mutually complementary relationship with various businesses in the region with the integrated wood production system of foresting, sawing, processing, and selling. Although the vitality of the local forestry and wood industry is declining as a whole, the wood production structure of Yamacho-Shoten resists the decline in regional vitality and guarantees the continuation of other forestry and wood production businesses. 